\title{
Linguistic Focus of Language Related Episodes in Intermediate and Advanced EFL Learners' Group-based Interactions: A Case Study
}

\author{
Zhila Mohammadnia (corresponding author) \\ Department of Language \& Literature, Faculty of Persian Literature and Foreign Languages, University of Tabriz, Tabriz, Iran \\ E-mail: mohammadnia@tabrizu.ac.ir \\ Abdolreza Khalili \\ Department of Language \& Literature, Faculty of Persian Literature and Foreign Languages, University of Tabriz, Tabriz, Iran \\ E-mail: reza_khalili_urmia@yahoo.com
}

Doi:10.7575/aiac.alls.v.5n.2p.127

URL: http://dx.doi.org/10.7575/aiac.alls.v.5n.2p.127
Received: 20/02/2014

Accepted: 09/04/2014

\begin{abstract}
The present study investigated linguistic focus of language related episodes (LREs), in Iranian EFL classrooms. Eighteen male participants in the advanced and intermediate levels from Urmia branch of Academic Centre of Education, Culture and Research (ACECR) participated in the study. They were assigned to intermediate and advanced levels with one class at each level, based on their results on a placement test. Then, the data were collected over five weeks, two one-hour sessions per week for each class during which the participants carried out some communicative tasks. Next, these interactions were analyzed to account for the types and contents of their LREs. The results revealed that L2 learners in both advanced and intermediate levels were primarily concerned with lexical LREs. Furthermore, based on the results it was found that incidental focus on form lended itself more easily to vocabulary teaching compared to other language components while grammar needs more explicit techniques of focus on form instruction.
\end{abstract}

Keywords: Focus on form, focus on forms, focus on meaning, Task-based Language Teaching, Language Related Episode (LRE)

\section{Introduction}

Over the recent decades, focus on form instruction has been one of the debated areas in the field of foreign/second language teaching. In the context of performing a communicative task this kind of instruction is related to incidentally directing the learners' attention to the linguistic forms in their tasks (Ellis, Basturkmen \& Loewen, 2001). The importance of the principles of Communicative Language Teaching (CLT) such as meaningful communication, and also the explicit study of the formal elements of the language are emphasized in this kind of instruction (Poole, 2004). Many studies have considered the effect of focus on form instruction on second language learning (e.g., Doughty 1991; Pica 1994; Spada \& Lightbown 1993).Some studies have considered the kinds of forms that learners attend to in second language contexts (e.g. Williams, 1999).However, only a few studies have considered the content of the forms that ESL learners attend to while performing communicative tasks (e.g. Poole, 2004).

Furthermore, there is little information on the kinds of forms and their content that the learners attend to in EFL contexts (Poole, ibid). The present study by examining the kinds of language forms and their content which learners attend to in EFL task-based language classrooms aims to determine the methods of focus on form instruction which are effective at intermediate and advanced EFL classrooms.

\section{Review of Related Literature}

\subsection{Focus on Meaning Instruction}

According to Long (1991) and Long and Robinson (1998) focus on meaning instruction is a communication-based approach to language teaching in which formal elements of the language are not treated in an intensive way. Furthermore, Long and Robinson (1998) claim that language use in situations which are very similar to the real life in which meaning and comprehension along with acceptable fluency in the use of language are vital, constitute the distinguishing features of this approach. Finally, they conclude that the main reason for meaning-focused language instruction is that learning the language is for using it as a tool rather than as a subject for study.

\subsection{Focus on Form and Focus on Forms Instructions}

According to Long (1991) there are two kinds of instructions which deal with the formal aspects of language including focus on forms and focus on form instructions. He further argued that, in focus on forms instruction some specific elements of a language are pre-selected based on a linguistic or structural syllabus and are treated in a systematic way during the language course. He finally concluded that, the main focus of attention in focus on forms instruction is on the formal aspects of the language. However according to Ellis et al. (2001), the meaning of second language is considered to be the main focus in focus on form instruction and this arises from communication-based activities in which L2 learners use the language as a tool for communication and not as a subject for study. 


\subsection{Tasks and Task-based Language Teaching}

Focus on form instruction is closely related to Task-based Language Teaching (Long, 1985). According to Skehan (1998) tasks are activities in which meaning is more important than the form and these activities deal with solving some communication-based problems. He further argued that tasks involve relationships to the activities in the real-world and the main goal for the learners is the completion of these tasks. Finally he concluded that tasks are assessed regarding their outcome.

However, although tasks are intended to have the main focus on the meaning, they involve a secondary focus on the formal elements of the language (Long, 1985). Considering this issue, Task-based Language Teaching has been defined in a different way by other researchers (e.g. Long, 1985; Long \& Crookes, 1992). Long (1985) emphasized the need for a conscious attention to the formal aspects of the languagein the process of communication and referred to this kind of attention as focus on form. He finally concluded that tasks should be designed to involve a main focus on the meaning and a secondary peripheral focus on the formal elements of the language.

According to Ellis (2003) there are some differences between task-based and task-supported approaches in second/foreign language teaching. He further argued that, in task-based language teaching, the basis for a whole language syllabus is provided through the use of tasks. However in task-supported language teaching tasks do not provide a means for the learners to restructure their developing interlanguage systems, or are not sources for new language knowledge and only play a role in the fluency enhancement of the L2 learners.

\subsection{Theoretical Bases of Focus on Form Instruction}

Traditionally a focus on the forms of second/foreign language which was operationalized by the use of structural or linguistic syllabi was the dominant trend in the field of second language learning and teaching (Richards \& Rodgers 2001). This obsession with the formal aspects of the language was evident in the popular language teaching methods of the time such as Audiolingualisim. With the rise of CLT, communication-based approaches such as Natural Approach (Terrell \& Krashen, 1983), in which there was a complete disregard of the formal elements of the language and which considered the meaning of language to be the only and main focus of language teaching came into vogue (Richards \& Rodgers, 2001). However these approaches had their own problems (Harley \& Swain, 1984) and because of the unsatisfactory results of both focus on forms and focus on meaning instructions, Long and Robinson (1998) introduced focus on form instruction which was considered to provide more promising results than its previous teaching approaches.Long and Robinson (1998, p. 23) defined focus on form as: "during an otherwise meaning focused classroom lesson, focus on form often consists of an occasional shift of attention to linguistic code features - by the teacher and/or one or more students - triggered by perceived problems with comprehension or production".

As mentioned previously few studies have examined the kinds of forms learners attend to in the process of their communicational exchanges. Williams' (1999) research is one of the few studies which have addressed this problem. In this study the researchers operationalized focus on form instruction through Swain and Lapkins' (1995) notion of Language-Related Episodes (LREs) and stated that LREs involve "discourse in which the learners talk or ask about language, or question, explicitly or implicitly, their own language use or that of others. Language use might include the meaning, spelling, or pronunciation of a word, the choice of grammatical inflection, word order, and so on"(Williams, 1999, p. 595).She distinguished five kinds of LREs discovered in learners' discourse including: learner-initiated requests to other learners, learner-initiated requests to the teacher, metatalk, negotiation, and other correction. She argued that, learner-initiated requests to other learners involve questions from one learner to another learner in a direct way and learner-initiated questions to the teacher involve direct questions which learners direct to their teachers. She further argued that, in metatalk, language learners in order to arrive at mutual understanding of a concept which is larger than the actual language form, focus on some particular formal elements of language. According to her, the difference between metatalk and negotiation is the purpose of discussion in negotiation which deals with clarifying communication-based problems which have a grammatical or a lexical misunderstanding as their source. Finally, she noted that, other correction is the process of perceiving and correcting an error by another learner or the teacher without any kind of request from the learner who made the error.

Another study which is closely related to Williams' (1999) study is the study by Poole (2004), which by considering the content of the forms which learners attend to in ESL contexts expanded Williams' (1999) study. As mentioned previously,according to (Long, 1985) and (Long \& Robinson, 1992), tasks have to be designed in ways that will involve a main focus on meaning but also will permitan incidental focus on the formal aspects of the language.

The present study by considering the original definition of focus on form by Long and Robinson (1998)and by adopting a task-based syllabus which is closely related to focus on form instruction (Long, 1985), tries to reveal the kinds of forms and their content which EFL learners attend to in their communicational activities by doing various kinds of tasks. Considering focus on form instruction, the classification of the different kinds of LREsdeveloped by Williams (1999), and considering the content of the LREs the classification developed by Poole (2004) is used in the present study.

\section{Methodology}

\subsection{Design of the Study}

The present study examined two separate classes which were in the advanced and intermediate proficiency levels with nine male learners in each group, and by comparing the results of these two proficiency levels tried to expand the previously cited studies and give a clear understanding of the issue. Therefore the study employed a case study design and through the use of percentages tried to describe the behavior of the groups and compare their results. 


\subsection{Participants}

The participants in the study were 18 male learners of English ranging in agefrom 15 to 26 who were from Urmia, and had studied English in Urmia branch of Academic Center for Education, Culture, and Research(ACECR), between 3 to 6 years. They were the researchers' students at ACECR that participated in their regular classes in the institute and also in the course which was designed by the researchers for the study as volunteers. Based on the participants English proficiency level which was determined by Objective Placement Test, from New Interchange Passages Placement and Evaluation Package (Lesley, Hansen, \& Zukowski/Faust, 2003) the researchers assigned participants to two classes, one intermediate level and one advanced level. Then each class was divided to three groups with three learners in each group. In order to prevent learners from forming sub-groupsthe researchers included learners of mixed ages in each group and encouraged the learners to actively participate in the group tasks. The researchers acted both as organizers and facilitators by observing the class and answering the learners' questions when they had task related problems.

\subsection{Materials}

\subsubsection{Homogeneity Test}

Objective Placement Test, from New Interchange Passages Placement and Evaluation Package (Lesley, Hansen, \& Zukowski/Faust, 2003) was used to place the participants in their appropriate proficiency levels and also to ensure their homogeneity in each level. This homogeneity test was comprised of four parts. The first part (Listening) consisted of twenty recorded items. The second part (Grammar) had a total of thirty items. The third part (Vocabulary) included a total number of thirty items, and the final part (Reading) consisted of twenty items.

\subsubsection{Communicative Tasks}

Most of the group work in the study was based on a range of carefully planned communicative tasks. Mostly these tasks included consensustasks in which groups of learners must finally agree on a certain issue, like the dictogloss task, and Jigsaw tasks which include a two-way oral interaction for putting the different pieces of information together to complete the tasksuch as a map task and a story completion or a story sequencing task in which parts of the story either inpictorial or written form are given to different learners and the learners are asked to make a complete story out of the separate parts. Most of the tasks were taken from Pica et al. (1993). No materials were used to direct learners' attention to language forms in these tasks.

\subsubsection{Clip-on Microphones}

During data collection 3 clip-on microphones were used to record the participants' interactions within each group in each level. The participants in each group sat around a table and the microphone was placed at the center of the table to record the voice of the participants in that group.

\subsection{Procedure}

In the present study first the researcher administered the Objective Placement Test, from New Interchange Passages Placement and Evaluation Package (Lesley, Hansen, \&Zukowski/Faust, 2003) to ensure participants' homogeneity before data collection. Based on the results of this test participants were assigned to intermediate and advanced proficiency levels.During the data collection the researchersthemselves acted as models and organizersfor the learners in both of the proficiency levels. At the beginning of each class the researchers first modeled the task for the class with the help of two students and then participants focused on a range of carefully planned tasks which were designed by the researchers for them with the main focus on communication and meaning comprehension. Data was collected during five weeks, two sessions each week for each class, and one hour each session during which participants focused on a range of communicative tasks. Totally ten hours of data were collected for each proficiency level over ten sessions during which the learners were tape-recorded with the help of 3 clip-on microphones for three groups in each proficiency level for recording learner-learner interactions within each of the groups.

\subsection{Data Analysis}

Tapes of students' interactions were analyzed for LRE categories and content by the researchers. In transcribing the LREs, Swain's (1998) conception of the term was used to guide the study. The five LREs categories were used to identify how students attended to form: (1) learner-initiated requests to other learners (2) learner-initiated questions to the teacher; (3) negotiation; (4) metatalk; (5) and other correction. "Content" in the present study refers to the specific lexical and grammatical types of LREs. More specifically as Poole (2004) argued the content refers to the lexical LREs which deal with the meaning, spelling, usage, and pronunciation of the individual words in the learners' communicative tasks. Furthermore as he argued grammatical LREs, involve items with a morphological or syntactical focus.

In analyzing the LRE categories the classification of Williams (1999) and in determining the content of the LREs the classification developed by Poole (2004) was used in the present study. In order to identify Williams' (1999) LRE categories, the researchers listened to the tapes and transcribed those sections in which they thought that LREs had occurred. Students were regarded as engaging in an LRE when they explicitly exchanged information with one or more peers about a grammatical or lexical form of the language. The researchers judged the end of the LREs when either the content of specific forms was overtly agreed upon by the learners or when the participants stopped explicitly talking about them. For example in extract 1 below, two learners from the first group of the intermediate level negotiate the meaning of the word intercom in the course of a story completion task:

\section{Extract 1}

L1: And then he pushes the intercom button

L2: Intercom?

L1: You don't know intercom?

L2: No I don't.

L1: It is something that you use to knock the door. It has a button and you use it and someone answer you. 
L2: Yes ok I understand it.

Another example from the second group in the advanced level is provided in extract 2 below and entails othercorrection during a dictogloss task:

Extract 2

L1: The teacher asked about the meditation

L2: No it was medication

L3: Yes it was medication because of the word pharmacy in the second paragraph.

Finally the last example from the first group in the advanced level which entailed metatalk during a dictogloss task is provided in extract 3 below:

Extract 3

L1: He recommended that Ahmad must be ready for tomorrow

L2: Did you say must be?

L1: Yes. WHY?

L2: I think it is not right to say must after the verb recommend. What do you think? (Asking the third learner)

L3: I think you are right. I remember from the grammar part that we must use the base form of the verb after some verbs like demand or insist. We can ask the teacher.

The researchers only transcribed the LREs as they occurred in the tape recordings, and after one week they returned to the transcriptions to revise them on the assumption that some mistakes might have occurred in the transcription but there were no such errors and only a few LREs were discarded from the data pool because of the noise problems in the tape recordings. Cohens' Kappa which represents the average rate of agreement for an entire set of data, accounting for the frequency of both agreements and disagreements among the raters was employed to measure inter-rater reliability. The results of this statistical test revealed an inter-rater reliability of 0.90 which is considered to be acceptable and satisfactory.

\section{Results}

The results show that in the intermediate class out of 59 forms $53(89.8 \%)$ were vocabulary while 6 forms involved morphosyntax (see Table 1). There was some variation among the groups and the range of the proportion of vocabulary to grammar changed from $87.5 \% / 12.5 \%$ (Group 3) to $94.4 \% / 5.6 \%$ (Group 2) thus all of the groups in intermediate class focused on vocabulary instead of grammar. Moreover, in the advanced class, 57 out of 62 individual forms involved vocabulary while 5 forms involved morphosyntax (see Table 2). Furthermore the range of the proportion of the vocabulary to grammar ranged from $90 \% / 10 \%$ (Group 3) to $95.2 \% / 4.7 \%$ (Group 2). Therefore in the advanced class too all of the groups focused on vocabulary instead of grammar. In the Intermediate class out of 59 forms $31(52.5 \%)$ were concerned with meaning, followed by pronunciation (13-22\%), spelling (5-8.4\%), adjective-form (3-5\%), voice and tense equally (2-3.3\%), and plural nouns, word choice and subject verb agreement equally (1-1.6\%) (see Table 3$)$. In the advanced group out of 61 form $32(51.6 \%)$ concerned meaning followed by pronunciation (14-22.5\%), spelling (6$9.6 \%)$, word choice (3-4.8\%), adjective form and tense equally (2-3.2\%), and plural nouns voice and subject verb agreement equally (1-1.6\%) (see Table 4). As can be seen in Table 5 and Table 6 , at least $48 \%$ of LREs in each group is concerned with meaning in the intermediate group and at least $47.6 \%$ of LREs in the advanced group is concerned with meaning.

Table 1. Types of Forms for Intermediate Learners

\begin{tabular}{rccc}
\hline Group & Vocabulary & Grammar & Total \\
\hline & 22 & 3 & 25 \\
1 & $88 \%$ & $12 \%$ & $100 \%$ \\
& 17 & 1 & 18 \\
2 & $94.4 \%$ & $5.6 \%$ & $100 \%$ \\
& 14 & 2 & 16 \\
3 & $87.5 \%$ & $12.5 \%$ & $100 \%$ \\
& 53 & 6 & 59 \\
Total & $89.8 \%$ & $10.1 \%$ & $100 \%$ \\
\hline
\end{tabular}

Table 2. Types of Forms for Advanced Learners

\begin{tabular}{cccc}
\hline Group & Vocabulary & Grammar & Total \\
\hline \multirow{1}{*}{$\mathbf{2}$} & 19 & 2 & 21 \\
& $90.4 \%$ & $9.5 \%$ & $100 \%$ \\
$\mathbf{2}$ & 20 & 1 & 21 \\
& $95.2 \%$ & $4.7 \%$ & $100 \%$ \\
$\mathbf{3}$ & 18 & 2 & 20 \\
& $90 \%$ & $10 \%$ & $100 \%$ \\
Total & 57 & 5 & 62 \\
\end{tabular}




\section{Table 3. Content of the Forms for Intermediate Class}

\begin{tabular}{|c|c|c|}
\hline Content & Frequency & Percent \\
\hline $\begin{array}{l}\text { Meaning } \\
\text { (V) }\end{array}$ & 31 & 52.5 \\
\hline $\begin{array}{c}\text { Pronunciation } \\
\text { (V) } \\
\text { Spelling }\end{array}$ & 13 & 22 \\
\hline $\begin{array}{l}\text { (V) } \\
\text { Tense }\end{array}$ & 5 & 8.4 \\
\hline $\begin{array}{c}(\mathrm{G}) \\
\text { Plural Nouns }\end{array}$ & 2 & 3.3 \\
\hline (G) & 1 & 1.6 \\
\hline $\begin{array}{c}\text { Adjective Form } \\
\text { (V) }\end{array}$ & 3 & 5 \\
\hline $\begin{array}{l}\text { Word Choice } \\
\text { (V) }\end{array}$ & 1 & 1.6 \\
\hline $\begin{array}{l}\text { Subject-Verb } \\
\text { Agreement } \\
\text { (G) } \\
\text { Voice } \\
\text { (G) }\end{array}$ & 1 & 1.6 \\
\hline Total & 59 & 100 \\
\hline
\end{tabular}

Key: V=Vocabulary; $\mathrm{G}=$ Grammar

Table 4. Content of the Forms for Advanced Class

\begin{tabular}{|c|c|c|}
\hline Content & Frequency & Percent \\
\hline $\begin{array}{l}\text { Meaning } \\
\text { (V) }\end{array}$ & 32 & 51.6 \\
\hline $\begin{array}{c}\text { Pronunciation } \\
\text { (V) }\end{array}$ & 14 & 22.5 \\
\hline $\begin{array}{l}\text { Spelling } \\
\text { (V) }\end{array}$ & 6 & 8.4 \\
\hline $\begin{array}{c}\text { Tense } \\
(\mathrm{G})\end{array}$ & 2 & 3.2 \\
\hline $\begin{array}{l}\text { Plural Nouns } \\
\qquad(\mathrm{G})\end{array}$ & 1 & 1.6 \\
\hline $\begin{array}{l}\text { Adjective Form } \\
\text { (V) }\end{array}$ & 2 & 3.2 \\
\hline $\begin{array}{l}\text { Word Choice } \\
\text { (V) }\end{array}$ & 3 & 4.8 \\
\hline $\begin{array}{l}\text { Subject-Verb } \\
\text { Agreement } \\
\text { (G) }\end{array}$ & 1 & 1.6 \\
\hline $\begin{array}{l}\text { Voice } \\
\text { (G) }\end{array}$ & 1 & 1.6 \\
\hline Total & 62 & 100 \\
\hline
\end{tabular}




\begin{tabular}{lcccccccccc} 
Group & $\mathrm{M}$ & $\mathrm{T}$ & $\mathrm{P}$ & $\mathrm{PN}$ & $\mathrm{S}$ & $\mathrm{WC}$ & $\mathrm{A}$ & $\mathrm{V}$ & $\mathrm{AF}$ & $\mathrm{TO}$ \\
\hline 1 & 12 & 1 & 5 & 1 & 3 & 1 & 0 & 1 & 1 & 25 \\
\%In group & 48 & 4 & 20 & 4 & 12 & 4 & 0 & 4 & 4 & 100 \\
$\quad 2$ & 11 & 1 & 5 & 0 & 1 & 0 & 0 & 0 & 0 & 18 \\
& & & & & & & & & & \\
\%In group & 61.1 & 5.5 & 27.7 & 0 & 5.5 & 0 & 0 & 0 & 0 & 100 \\
$\quad 3$ & 8 & 0 & 3 & 0 & 1 & 0 & 1 & 1 & 2 & 16 \\
\%In group & 50 & 0 & 18.75 & 0 & 6.25 & 0 & 6.25 & 6.25 & 12.5 & 100 \\
Total & 31 & 2 & 13 & 1 & 5 & 1 & 1 & 2 & 3 & 59 \\
\%In group & 52.5 & 3.3 & 22 & 1.6 & 8.4 & 1.6 & 1.6 & 3.3 & 5 & 100 \\
\hline
\end{tabular}

Key: $\mathrm{M}=$ Meaning; $\mathrm{T}=$ Tense; $\mathrm{P}=$ Pronunciation; $\mathrm{PN}=$ Plural Nouns; $\mathrm{S}=$ Spelling, $\mathrm{WC}=$ Word Choice; $\mathrm{A}=$ Subject-Verb Agreement; $\mathrm{V}=$ Voice; $\mathrm{AF}=$ Adjective Form; $\mathrm{TO}=$ Total

Table 6. Content of Forms within Groups for Advanced Class

\begin{tabular}{ccccccccccc} 
Group & M & T & P & PN & S & WC & A & V & AF & TO \\
\hline 1 & 12 & 1 & 4 & 1 & 2 & 0 & 0 & 0 & 1 & 21 \\
& & & & & & & & & & \\
\%In group & 57.14 & 4.7 & 19 & 4.7 & 9.5 & 0 & 0 & 0 & 4.7 & 100 \\
2 & 10 & 1 & 5 & 0 & 2 & 1 & 0 & 1 & 1 & 21 \\
\%In group & 47.6 & 4.7 & 23 & 0 & 9.5 & 4.7 & 0 & 4.7 & 4.7 & 100 \\
3 & 10 & 0 & 5 & 0 & 2 & 2 & 1 & 0 & 0 & 20 \\
\%In group & 50 & 0 & 25 & 0 & 10 & 10 & 5 & 0 & 0 & 100 \\
Total & 32 & 2 & 14 & 1 & 6 & 3 & 1 & 1 & 2 & 62 \\
& & & & & & & & & & \\
\%In group & 51.6 & 3.2 & 22.5 & 1.6 & 9.6 & 4.8 & 1.6 & 1.6 & 3.2 & 100
\end{tabular}

Key: M=Meaning; $\mathrm{T}=$ Tense; $\mathrm{P}=$ Pronunciation; $\mathrm{PN}=$ Plural Nouns; $\mathrm{S}=$ Spelling, $\mathrm{WC}=$ Word Choice; $\mathrm{A}=$ Subject-Verb Agreement; $\mathrm{V}=$ Voice; $\mathrm{AF}=$ Adjective Form; $\mathrm{TO}=$ Total

\section{Discussion and Conclusion}

Although there were differences in the design and context of the present study with the studies by Williams (1999) and Poole (2004), the results of the present study supported the results of the previous studies. This study by investigating the kinds of forms and their content in the advanced and intermediate levels expanded the previous studies and also tried to answer whether learners in EFL contexts focus on the similar forms as learners in ESL contexts or not. The findings of the present study suggest that the kinds of forms and their content that learners attend to in EFL contexts is very similar to the forms along with their content in ESL contexts. Firstly in both intermediate and advanced classes most of the forms that the learners focused on involved vocabulary and only a minor part of the forms were related to grammatical forms, and secondly the content of the forms in both the advanced and intermediate levels involved meaning of the words followed by pronunciation and spelling which support the findings of Poole (2004).

According to Fotos (2002), in foreign language settings, in which a large amount of target language input is not available an explicit approach is required for second language teaching. A more explicit and obtrusive approach than incidental focus on form can be found in the Processing Instruction procedures of VanPatten (1996). It is argued that the reason for the effectiveness of this approach lies in its activities which require learners to attend to form in order to process meaning (VanPatten, 1996; VanPatten \& Lee, 1995). Ellis $(1998,2001)$ uses the term, structured input for Processing Instruction and argues that this approach is a kind of focus on forms instruction since the main attention in this approach is given to the formal aspects of the language rather than the meaning. Based on the findings of the present study it may be argued that incidental focus on form may be more effective in vocabulary teachingfor EFL learners but not for grammatical features, and more explicit and planned forms of instruction like Processing Instruction procedures (VanPatten, 1996) may be needed to teach grammatical aspects of the language to learners in EFL contexts. However more research studies must be conducted before reaching firm conclusions and future research must address the issue involving larger number of learners in different proficiency levels. Finally it is hoped that curriculum 
designers and teachers may benefit from the results of the present study in developing materials and employing appropriate classroom techniquesfor the vocabulary and grammar learning of students in the EFL contexts.

\section{References}

Doughty, C (1991). Second language instruction does make a difference: Evidence from an empirical study of ESL relativization. Studies in SecondLanguage Acquisition, 13, 431-469

Ellis, R. (1998). Teaching and research: Options in grammar teaching. TESOL Quarterly, 32, 39-60.

Ellis, R. (2001). Introduction: Investigating form-focused instruction. Language Learning, 51, 1-46.

Ellis, R. (2003). Task- based language learning and teaching. Oxford University Press, Oxford.

Ellis, R., Basturkmen, H., \&Loewen, S. (2001). Doing focus-on-form.System, 30, 419-432.

Fotos, S. (2002). Structure-based interactive tasks for the EFL grammar learner. In E. Hinkel \& S. Fotos (Eds.), New perspectives on grammar teaching in second language classrooms (pp. 135-154). Mahwah, NJ: Lawrence Erlbaum Associates.

Harley, B., \& Swain, M. (1984).The interlanguage of immersion students and its implications forsecond language teaching.In A. Davies, C. Criper\& A. Howwat (Eds).Interlanguage (pp. 291-311). Edinburgh, Britain: Edinburgh University Press.

Lesly, T., Hansen, Ch., \& Zukowski/Faust, J. (2003).New interchange passages placement andevaluation package. New York, NY: Cambridge University Press.

Long, M. (1985). A role for instruction in second language acquisition: Task-based language teaching. In K. Hyltenstam \& M. Pienemann (Eds.), Modelling and assessing second language acquisition (pp. 377-393). Clevedon, UK: Multilingual Matters.

Long, M. (1991). Focus on form: A design feature in language teaching methodology. In K. DeBot, R. Ginsberg, \& C. Kramsch (Eds.), Foreignlanguage research in cross-cultural perspective (pp. 39-52).John Benjamin, Amsterdam.

Long, M., \& Crookes, G. (1992). Three approaches to task-based syllabus design. TESOL Quarterly, 26, 27-56.

Long, M., \& Robinson, P. (1998). Focus on form: Theory, research, and practice. In C. Doughty \& J. Williams (Eds.), Focus on form instruction in classroom second language acquisition (pp. 15-63). Cambridge: Cambridge University Press.

Pica, T., Kanagy, R. \&Falodun, J. (1993). Choosing and using communicative tasks for second language instruction. In G. Crookes \& S. M. Gass (Eds.) Tasks in a pedagogical context. Cleveland, UK: Multilingual Matters.

Poole, A. (2004). An exploratory study of focus on form instruction: How advanced ESL writers attend to form during group work. Asian Journal of English Language Teaching, 14, 119-134.

Richards, J. C., \& Rodgers, S. (2001). Approaches and methods in language teaching (2 ${ }^{\text {nd }}$ Ed.). UK: Cambridge University Press.

Skehan, P. (1998). A cognitive approach to language learning. Oxford: Oxford University Press.

Spada, N. \& Lightbown, P. (1993).Instruction and the development of questions in L2 classroom.Studies in Second Language Acquisition, 15, 205-221.

Swain, M. (1998). Focus on form through conscious reflection. In C. Doughty \& J. Williams (Eds.), Focus on form instruction in classroom second language acquisition (pp. 64-82). Cambridge: Cambridge University Press.

Swain, M., \& Lapkin, S. (1995). Problems in output and the cognitive processes they generate: A step towards second language learning. Applied Linguistics, 16, 371- 391.

Terrell, T., \& Krashen, S. (1983).Natural approach: Language in the classroom. Oxford: Alemany Press.

VanPatten, B. (1996). Input processing and grammar instruction. New York: Ablex.

VanPatten, B., \& Lee, J. (1995).Making communicative language happen.New York: McGraw-Hill.

Williams, J. (1999). Learner-generated attention to form.Language Learning, 49(4), 583-625. 